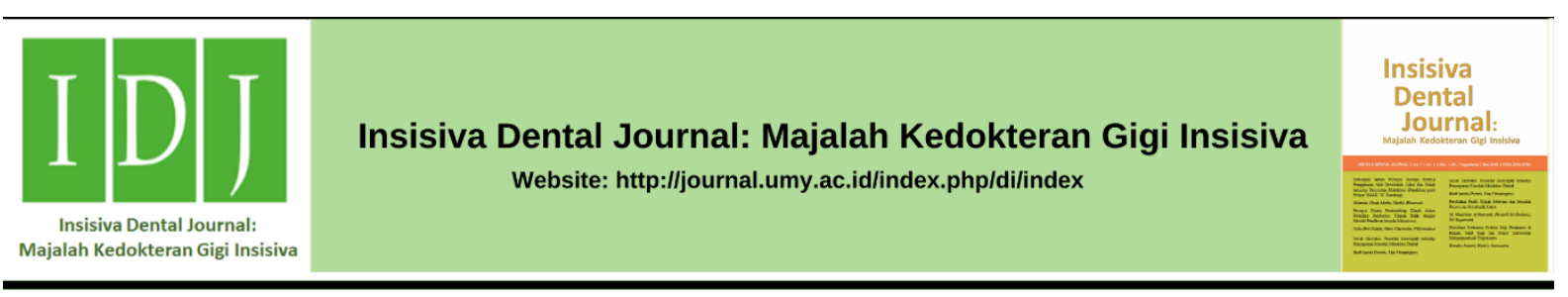

Research Article

\title{
Pemberian Madu Rambutan (Nephelium lappaceum) Menurunkan Luas Luka dan Kadar Malondialdehid Tikus Diabetes Melitus
}

\author{
Rambutan Honey (Nephelium lappaceum) Reduces Wound Area and Malondialdehyde in Diabetic Rats
}

\author{
Euis Reni Yuslianti ${ }^{1} *$, Afifah B. Sutjiatmo ${ }^{2}$, Dita Septiani ${ }^{3}$ \\ ${ }^{1}$ Departemen Biomedik dan Biologi Oral, Fakultas Kedokteran Gigi, Universitas Jenderal Achmad Yani Cimahi, Jalan Terusan Jenderal \\ Sudirman, Cimahi, Jawa Barat, Indonesia. \\ ${ }^{2}$ Departemen Farmakologi, Fakultas Farmasi, Universitas Jenderal Achmad Yani Cimahi, Jalan Terusan Jenderal Sudirman, Cimahi, Jawa \\ Barat, Indonesia. \\ ${ }^{3}$ Mahasiswa Program Magister Biologi Oral, Fakultas Kedokteran Gigi, Universitas Indonesia, Jalan Raya Salemba, Jakarta, Indonesia.
}

Received date: Feb $7^{\text {th }}, 2020$; reviewed date: Sept $2^{\text {nd }}, 2020$; revised date: March $24^{\text {th }}, 2021$; accepted date: April $21^{\text {st }}, 2021$

DOI : 10.18196/di.v10i1.8245

\begin{abstract}
Abstrak
Diabetes melitus merupakan kelainan metabolik yang disebabkan oleh kenaikan kadar gula darah. Luka pada penderita diabetes dapat menjadi ulkus yang melibatkan radikal bebas. Madu rambutan mengandung tinggi antioksidan yang berfungsi sebagai penyembuhan luka. Tujuan penelitian adalah untuk mengetahui pengaruh madu rambutan terhadap luas luka dan kadar Malondialdehid (MDA) mukosa mulut tikus Wistar diabetes melitus. Metode penelitian adalah eksperimental laboratoris. Sampel penelitian menggunakan 36 ekor tikus jantan galur Wistar. Semua tikus diinduksi aloksan untuk mendapatkan keadaan diabetes, kecuali kelompok kontrol negatif. Semua tikus diberi perlukaan dengan menggunakan punch biopsy berdiameter $4 \mathrm{~mm}$ pada palatum dalam kelompok kontrol positif, kontrol negatif, dan kelompok madu rambutan. Terminasi dilakukan pada hari ke-0, ke3, ke-7, dan ke-14 sebanyak 3 ekor tikus pada setiap kelompok serta dilakukan pengukuran luas luka dan pembacaan MDA jaringan. Uji analisis statistik menggunakan uji One Way ANOVA dan uji Kruskall Wallis (p < 0,05). Hasil penelitian menunjukkan madu rambutan dapat menurunkan luas luka pada hari ketujuh dan keempat belas serta menurunkan kadar radikal bebas MDA luka diabetes melitus. Kesimpulan dari penelitian ini adalah pemberian madu rambutan dengan kandungan antioksidan dapat menurunkan luas luka dan kadar radikal bebas malondialdehid plasma darah tikus diabetes sehingga berpotensi untuk obat penyembuh luka rongga mulut manusia dengan diabetes melitus.
\end{abstract}

Kata Kunci: Diabetes Melitus; Madu Rambutan; Malondialdehid; Luka

\begin{abstract}
Diabetes mellitus is a metabolic disorder caused by a rise in blood sugar levels. Patients with diabetes mellitus are very susceptible to complications, one of which wound healing problems. Problem wounds in patients with diabetes mellitus is usually only realized when the wound has become ulcers and involves free radical. Honey rambutan contain high antioxidants that function as wound healing. The aims of this study is to understand the effect of rambutan honey towards the wound and the Malondialdehyde (MDA) level of rat oral mucosa having diabetes mellitus. Methods was a laboratory experimental research. The subjects were 36 males Wistar furrow rats. All the rats were induced by alloxan to get the state of diabetes, except the negative control group. Then all rats were wounded with a diameter of $4 \mathrm{~mm}$ biopsy punch on the palate and divided into positive control groups, negative control groups, and topical rambutan honey groups. Termination was done on day $0,3^{\text {rd }}, 7^{\text {th }}$, and $14^{\text {th }}$ to 3 rats sacrificed from each group. The measurement of wound size and MDA level was also performed. Statistical analysis test used in this research was One Way ANOVA test and Kruskal-Wallis test ( $p<0,05)$. Results of this study showed that rambutan honey has an effect towards the reduction of wound area on the proliferative phase
\end{abstract}

\footnotetext{
* Corresponding author, e-mail: ery.unjani@yahoo.co.id
} 
and remodelling phase and the decrease of MDA level of diabetes mellitus rat. In conclusion, rambutan-honey potentially reduce wound area and malondialdehyde level/stress oxidative in diabetic rats. Thus, our finding provides clear evidences that rambutan-honey have a potential as a natural treatment for diabetic human oral mucosa wound healing.

Keywords: Diabetes Melitus; Malondialdehyde; Rambutan Honey; Wound

\section{PENDAHULUAN}

Data WHO pada tahun 2014 melaporkan bahwa penduduk yang mengalami penyakit diabetes melitus di dunia telah mencapai 347 juta dan 80 persen kasus terjadi di negara berkembang. Pada tahun 2012, sekitar 1,5 juta orang meninggal akibat penyakit diabetes dan diperkirakan pada tahun 2030 jumlah kematian akibat diabetes akan meningkat sampai dua kali lipat. Di Indonesia pada tahun 2001, penderita diabetes melitus mencapai 17 juta orang dan menduduki urutan keempat sebagai negara terbesar yang memiliki jumlah penderita diabetes melitus. Menurut studi epidemiologi, diperkirakan pada tahun 2030 prevalensi diabetes melitus di Indonesia mencapai 21,3 juta orang. $\frac{1,2}{}$

Pasien diabetes melitus dapat mengalami komplikasi makrovaskular dan mikrovaskular. ${ }^{3}$ Kondisi stres oksidatif penderita diabetes melitus mengakibatkan disfungsi endotel yang berpengaruh pada angiogenesis, remodeling vaskular, dan penyembuhan luka di tubuhnya. ${ }^{4}$ Penelitian hewan coba telah melaporkan mekanisme penyembuhan luka mencit hiperglikemik..$^{\frac{5}{}}$ Penyembuhan luka normal terdiri dari fase hemostasis dan inflamasi (hari pertama sampai hari kelima, fase proliferasi dimulai hari ketujuh dan fase remodeling dimulai dari minggu kedua setelah luka. $\underline{6}$

Dewasa ini masyarakat mulai beralih menggunakan obat-obatan dari bahan alam karena obat-obatan berbahan kimia dikenal memiliki efek samping bagi kesehatan tubuh. Selain pengobatannya yang mudah dan murah, obat-obatan herbal juga memiliki efek samping seminimal mungkin karena komposisinya terdiri dari bahanbahan alami. ${ }^{7}$

Salah satu bahan alami yang memiliki banyak khasiat bagi kesehatan adalah madu. Madu merupakan sumber antioksidan yang baik untuk tubuh. Konsumsi madu dapat meningkatkan aktivitas antioksidan dalam tubuh. Menurut beberapa sumber penelitian, madu juga memiliki aktivitas farmakologis lain, yaitu sebagai antibakteri, antimutagenik, antitumor, antiinflamasi, penurunan kadar kolesterol, vasodilator sehingga baik untuk penderita diabetes. Di Indonesia terdapat beberapa jenis madu yang diproduksi secara kontinu, salah satunya adalah madu rambutan (Nephelium lappaceum). Yuslianti et al. pada tahun 2015 melaporkan bahwa madu rambutan mempunyai aktivitas antioksidan dan dapat mempercepat penyembuhan luka mukosa mulut in vivo. Penelitian aktivitas antioksidan secara in vitro seperti madu Venezuela dapat menurunkan reaksi peroksidasi lipid penghasil malondialdehid (MDA). Penelitian dilakukan pada luka eksisi tikus normal namun pengaruh madu rambutan pada luka mukosa mulut penderita diabetes belum diketahui. ${ }^{8}, 9$ Peneliti ingin mengetahui pengaruh madu rambutan (Nephelium lappaceum) terhadap penyembuhan luka pada mukosa mulut tikus galur wistar diabetes yang diinduksi aloksan dilihat dari penurunan ukuran luas luka dan kadar MDA. Malondialdehid merupakan senyawa yang dihasilkan dari proses peroksidasi lipid, digunakan sebagai marker untuk penanda stres oksidatif yaitu radikal bebas dari sel dan jaringan termasuk luka diabetes melitus.

\section{MATERIAL DAN METODE}

Penelitian menggunakan eksperimen laboratoris bersifat analitik yang telah disetujui Komisi Etik Penelitian Fakultas Kedokteran Universitas Padjadjaran dengan nomor: 209/UN6.C10/PN/2017. Penelitian ini 
dilakukan di Laboratorium Biokimia dan Laboratorium Percobaan Hewan Fakultas Kedokteran Universitas Jenderal Achmad Yani.

Tikus galur wistar (Rattus norvegicus) dari famili Muridae yang berjumlah 36 ekor diperoleh dari unit perkembangan hewan Biofarma Bandung dengan kriteria inklusinya adalah berusia antara 3 sampai 4 bulan, jantan, berat badan 150-250 gram, sehat ditandai dengan pergerakan aktif, makan dan minum tidak bermasalah, serta memiliki respons terhadap rangsangan yang baik dan didapatkan dari tempat pembiakan yang sama dengan pakan tikus yang sama dan perlakuan yang sama. $., \underline{11}, \underline{12}$

Tikus diberikan waktu adaptasi selama 7 hari. Hari ke-8 tikus kelompok negatif diberi pakan pelet standar 30 g/hari/ekor dan diberi minum secara ad libitum sampai akhir penelitian sedangkan kelompok positif dan perlakuan pada hari ke-8 dilakukan induksi aloksan dengan dosis $120 \mathrm{mg} / \mathrm{KgBB}$ secara intraperitoneal. Setelah 96 jam induksi aloksan, kadar gula darah dianalisis yaitu pada hari ke-11 sampai didapatkan kondisi hiperglikemia pada tikus (kadar glukosa puasa lebih dari $120 \mathrm{mg} / \mathrm{dL}$ ) sebelumnya dipuasakan selama 12 jam melalui pengumpulan sampel darah secara langsung dari ekor. Tikus diabetes dilakukan prosedur penelitian dengan dilakukan perlukaan menggunakan punch biopsy berdiameter $4 \mathrm{~mm}$ dengan kedalaman $2 \mathrm{~mm}$ pada palatum (Gambar 1). Sampel dibagi menjadi kelompok kontrol positif (P1) yaitu tikus yang diberikan induksi aloksan sehingga diabetes serta diberi perlukaan kemudian diberi povidine iodine topikal, kontrol negatif (P2) yaitu tikus tanpa induksi aloksan kemudian diberi perlukaan kemudian diberi povidine iodine topikal, dan kelompok madu rambutan (P3) yaitu tikus diabetes serta diberikan perlukaan dan pemberian madu rambutan topikal. Observasi dan terminasi dilakukan dengan cara tikus di euthanasia melalui inhalasi karbodioksida $\left(\mathrm{CO}_{2}\right)$. Pada hari ke0 , ke-3, ke-7, dan ke-14 sebanyak 3 ekor tikus dari 12 ekor tikus pada setiap kelompok diterminasi kemudian dilakukan pengukuran luas luka dengan menggunakan kaliper ukur digital sebanyak empat kali mengukur diameter terluar luka. Jaringan palatum diambil di sekitar perlukaan seluas 1 sentimeter dan sebanyak 0,2 gram dihancurkan dengan setetes larutan Sodium Dodecyl Sulfate (SDS) untuk pengukuran kadar malondialdehid.

Metode pemeriksaan MDA menggunakan TBARs dengan hasil absorbansi dibaca spektrofotometer. Metode TBARs menggunakan bahan larutan asam asetat $(20 \mathrm{ml}$ asam asetat $96 \%$

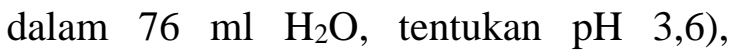
Larutan asam tiobarbiturat (larutkan 0,8 asam 2-tiobarbiturat dengan $7 \mathrm{ml} \mathrm{NaOH} 1 \mathrm{~N}$ tambahkan $\mathrm{H}_{2} \mathrm{O}$ sampai $100 \mathrm{ml}$, tentukan $\mathrm{pH} 3,6)$, Larutan butylated hydroxytoluene (BHT) (44 mg butylated hidroxytoluene dalam $5 \mathrm{ml}$ etanol absolut), larutan EDTA (1,488 g EDTA dalam $50 \mathrm{ml} \mathrm{H}_{2} \mathrm{O}$ selalu dibuat baru), dan larutan standar. Prosedur dimulai dengan memasukkan $400 \mu$ plasma darah tikus diabetes tanpa pemberian madu rambutan ke dalam tabung reaksi 1 dan diberi label (P1), plasma darah tikus normal tidak diabetes dan tanpa perlakuan madu rambutan ke dalam tabung reaksi 2 dan diberi label (P2), dan plasma darah tikus diabetes dengan pemberian madu rambutan ke dalam tabung reaksi 3 dan diberi label (P3). Semua tabung reaksi ditambah akuades $300 \mu 1$, larutan SDS $200 \mu 1$, larutan BHT $50 \mu \mathrm{l}$, larutan EDTA $50 \mu \mathrm{l}$, larutan asam asetat 1,5 ml, dan larutan TBA 1,5 ml. Peneliti kemudian menginkubasi semua tabung dalam waterbath suhu $100{ }^{\circ} \mathrm{C}$ selama 30 menit dan menutup setiap tabung dengan kelereng. Selanjutnya setiap tabung direndam dalam bak air es. Melakukan sentrifugasi dengan kecepatan $3000 \mathrm{rpm}$ selama 10 menit. Mengambil supernatan dari setiap tabung dan membaca absorbansinya dengan spektrofotometer pada $\lambda 532 \mathrm{~nm}$ dengan satuan $\mu \mathrm{M} \cdot \underline{13}$

Madu rambutan didapatkan dari Perhutani. Aplikasi madu rambutan 
dioleskan pada luka dan dilakukan sehari dua kali setiap jam 6 pagi dan 6 malam.
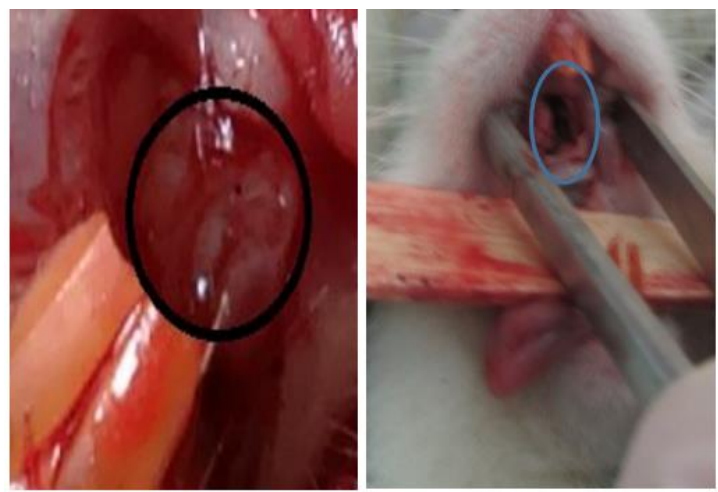

Gambar 1. Perlukaan mukosa mulut tikus pada awal perlukaan.

Pengaruh madu rambutan terhadap penurunan luas luka dan kadar malondialdehid mukosa mulut tikus galur wistar diabetes melitus, dianalisis menggunakan SPSS versi 22 dengan uji One Way ANOVA dan uji Kruskall Wallis untuk melihat perbedaan luas luka dan kadar MDA pada kelompok kontrol negatif, kontrol positif, dan kelompok eksperimen.

\section{HASIL}

Pengaruh madu rambutan terhadap luas luka jaringan mukosa mulut tikus diabetes dilihat dari nilai rerata setiap kelompok pada awal perlukaan (hari ke-0 perlukaan), fase inflamasi (hari ke-3 setelah perlukaan), fase proliferasi (hari ke-7 setelah perlukaan), dan fase remodeling (hari ke-14 setelah perlukaan) dapat dilihat pada Gambar 2 berikut.

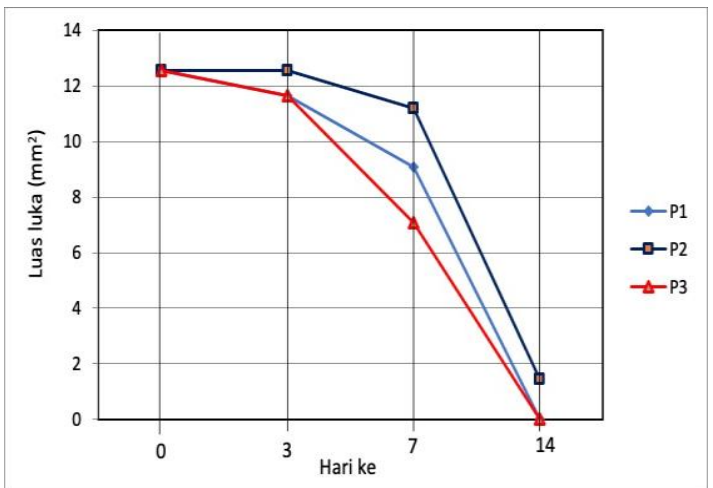

Gambar 2. Grafik penurunan luas luka pada kelompok positif (P1), kelompok negatif (P2), dan kelompok madu rambutan (P3)
Pada Gambar 2 terlihat perubahan luas luka dari hari ke 0-14. Hasil uji statistik menggunakan uji Kruskall Wallis karena data tidak terdistribusi normal dan tidak homogen. Hasil menunjukkan bahwa penurunan yang signifikan hanya terjadi pada hari ke-7 (fase proliferasi) dan hari ke14 (fase remodeling).

Perbedaan luas luka antarkelompok perlakuan pada hari ke-7 (fase proliferasi) dapat dilihat pada Tabel 1 berikut.

Tabel 1. Hasil uji beda luas luka antarkelompok perlakuan pada hari ke-7 (fase proliferasi).

\begin{tabular}{llc} 
Kelompok & Nilai $p$ & Kesimpulan \\
\hline P1 vs P2 & $0,046^{*}$ & Bermakna \\
P1 vs P3 & $0,043^{*}$ & Bermakna \\
P2 vs P3 & $0,046^{*}$ & Bermakna \\
\hline
\end{tabular}

Keterangan: Uji Mann-Whitney dengan (*): $\mathrm{p}<$ 0,05 (bermakna)

P1:kelompok positif, P2:kelompok negatif, P3: kelompok madu rambutan

Pada Tabel 1 menunjukkan semua kelompok pada uji memiliki perbedaan yang signifikan dengan nilai $(\mathrm{p}<0,05)$.

Perbedaan luas luka antarkelompok perlakuan pada hari ke-14 (fase remodeling) dapat dilihat pada Tabel 2 berikut.

Tabel 2. Hasil uji beda luas luka antar kelompok perlakuan pada hari ke-14 (fase remodeling).

\begin{tabular}{lcc} 
Kelompok & Nilai $\mathrm{p}$ & Kesimpulan \\
\hline P1 vs P2 & $0,037^{*}$ & Bermakna \\
P1 vs P3 & 0,317 & $\begin{array}{c}\text { Tidak } \\
\text { bermakna }\end{array}$ \\
P2 vs P3 & $0,046^{*}$ & Bermakna \\
\hline
\end{tabular}

Keterangan: Uji Mann-whitney dengan (*): $\mathrm{p}<$ 0,05 (bermakna)

P1:kelompok positif, P2:kelompok negatif, P3: kelompok madu rambutan

Tabel 2 menunjukkan bahwa terdapat perbedaan yang signifikan pada antar kelompok perlakuan pada fase remodeling terhadap luas luka $(\mathrm{p}<0,05)$.

Pengaruh madu rambutan terhadap kadar MDA luka jaringan mukosa mulut tikus diabetes dilihat dari nilai rerata tiap kelompok pada awal perlukaan, fase inflamasi, fase 
proliferasi, dan fase remodeling seperti pada Gambar 3 berikut. ${ }^{18}$

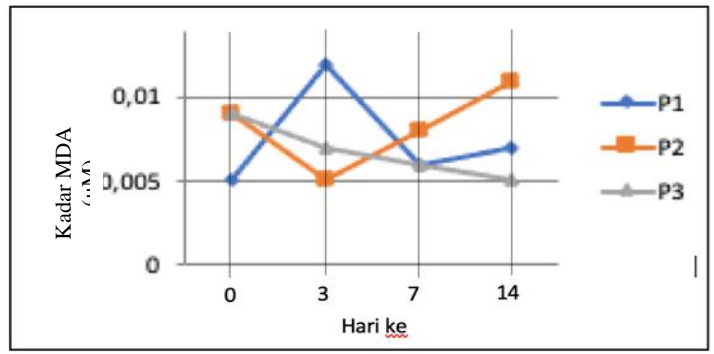

Gambar 3. Pengaruh madu rambutan terhadap kadar MDA mukosa mulut kelompok positif (P1), kelompok negatif (P2), dan kelompok madu rambutan $(\mathrm{P} 3)$
Pada Gambar 3 terjadi penurunan pada semua kelompok perlakuan, akan tetapi jika dilihat dari hasil uji statistik menggunakan uji One Way ANOVA menunjukkan bahwa penurunan yang signifikan terjadi pada kelompok perlakuan di hari ke-14 (fase remodeling).

Perbedaan antar kelompok perlakuan pada hari ke-14 (fase remodeling) dapat dilihat pada Tabel 3 berikut.

Tabel 3. Hasil uji beda kadar MDA kelompok tikus diabetes hari ke-14 (fase remodeling)

\begin{tabular}{llll}
\hline Kelompok & Kelompok & Nilai $\mathrm{p}$ & Kesimpulan \\
& Pembanding & & \\
\hline P1 & P2 & $0,034^{*}$ & Bermakna \\
& P3 & 0,966 & Tidak bermakna \\
P2 & P1 & $0,034^{*}$ & Bermakna \\
& P3 & $0,046^{*}$ & Bermakna \\
P3 & P1 & 0,966 & Tidak bermakna \\
& P2 & $0,046^{*}$ & Bermakna \\
\hline
\end{tabular}

Keterangan: Uji Post hoc: Tukey dengan (*): $\mathrm{p}<0,05$ (bermakna)

P1: kelompok positif , P2:kelompok negatif, P3: kelompok madu rambutan

\section{PEMBAHASAN}

Jumlah sel-sel inflamasi dan kadar radikal bebas terbilang tinggi pada saat perlukaan dan fase inflamasi sehingga belum terbentuk penyembuhan luka yang optimal. Selain itu pada awal pemberian madu rambutan, madu rambutan dianggap sebagai benda asing oleh imunitas tubuh sehingga kadar malondialdehid pada fase inflamasi terbilang tinggi. ${ }^{14}$ Pada awal perlukaan hasil kelompok perlakuan madu rambutan tidak menunjukkan hasil bermakna, hal ini disebabkan karena efektivitas madu rambutan belum terlihat pada awal perlukaan dan pada fase inflamasi, jumlah sel-sel inflamasi masih terbilang tinggi sehingga belum terbentuk penyembuhan luka yang optimal. $\underline{15}$

Pada fase proliferasi sel granulasi berperan dalam penutupan luka. Sel granulasi akan menutup luka mulai dari tepi luka dengan bantuan dari sel fibroblas yang akan menghasilkan KGF sehingga sel-sel epidermal pada tepi luka akan bermitosis dan mulai menutup luka. $\frac{15}{}$

Pada fase remodeling sel-sel baru telah terbentuk dan sel-sel epidermis telah menutupi permukaan luka sehingga luka telah menutup. Proses ini dapat memakan waktu berbulan-bulan sebelum seluruh selsel berlebih diserap kembali oleh tubuh. $\underline{16}$

Dari Tabel 3 menunjukkan ada perbedaan yang signifikan dari setiap kelompok perlakuan. Hal ini diduga karena pada kelompok tikus galur Wistar diabetes, penyembuhan luka terganggu oleh efek dari diabetes melitus. Penyembuhan luka pada mukosa mulut tikus galur Wistar dapat terhambat karena efek dari diabetes melitus salah satunya adalah kerusakan pada saraf sensoris yang diakibatkan oleh neuropatik diabetik, selain itu penyembuhan luka dapat terhambat dikarenakan sel-sel imun menurun karena terjadi penurunan imunitas tubuh yang disebabkan karena turunnya kadar insulin dalam tubuh. $\underline{\underline{17}}$ 
Pada awal perlakuan terdapat pendarahan yang terjadi pada mukosa palatum tikus setelah dilakukan perlukaan terlihat luka dengan diameter $4 \mathrm{~mm}$. Hal ini terjadi dikarenakan punch biopsy dengan kedalaman $2 \mathrm{~mm}$ ketika perlukaan mengenai membran basalis yang terdapat banyak pembuluh darah.

Pengaruh madu rambutan terhadap luas luka tikus diabetes pada hari ke-0, ke3, ke-7, dan ke-14 dibandingkan dengan kelompok negatif dan positif dapat dilihat pada Gambar 4 berikut.

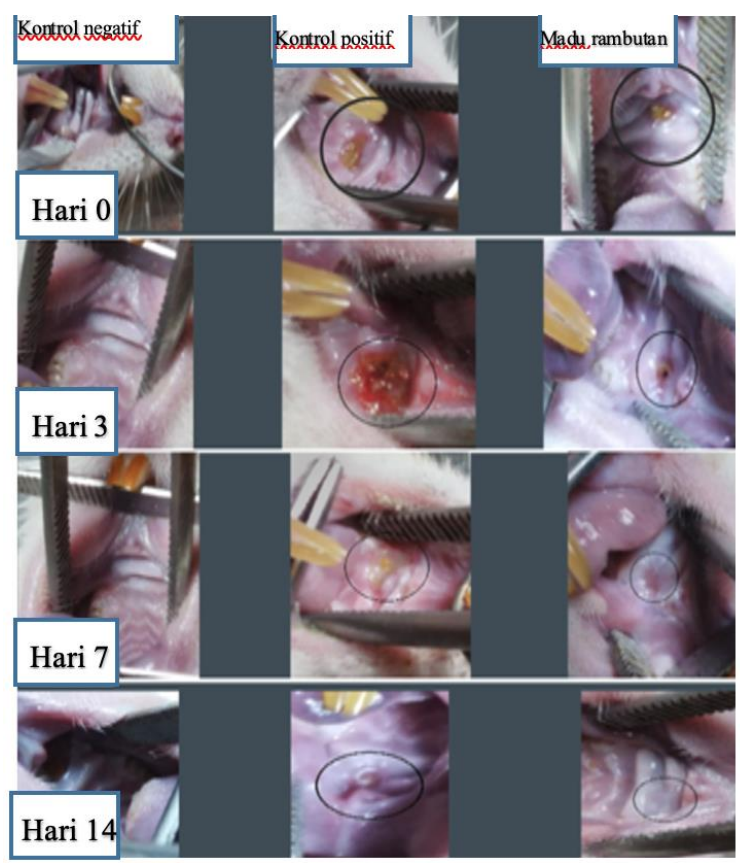

Gambar 4. Gambaran klinis luka mukosa oral pada tikus diabetes antar kelompok perlakuan.

Pada hari ke-3, proses penyembuhan luka berjalan lambat. Hal ini diketahui saat dilakukan rangsangan pada luka diabetes masih terdapat darah yang keluar dari luka tersebut. Dari gambaran klinis tersebut, pada hari ketiga proses pembekuan darah berjalan dengan lambat. Masalah ini juga terjadi pada kelompok perlakuan yang diberikan madu rambutan. Pada hari ke-7, mulai tampak proses penyembuhan luka yang ditandai dengan daerah berwarna merah pada sisi luar luka tikus diabetes yang artinya terjadi pembentukan pembuluh darah baru. Pembuluh darah kapiler yang baru akan terus memberikan nutrisi untuk perkembangan kolagen.
Setelah itu kolagen menyediakan tempat dan mendukung pembuluh darah kapiler yang baru terbentuk. Pada hari ke-14, luka pada tikus diabetes belum menutup seluruhnya. Hal ini dapat dilihat dari permukaan mukosa palatum tikus yang terlihat pada daerah luka masih tampak permukaannya lebih ke dalam daripada daerah mukosa normal sekitarnya dan terdapat warna kemerahan sedangkan pada luka normal dan luka diabetes yang diberikan madu rambutan sudah menutup. $.^{17,}, \underline{18}, \underline{19}$

Pemberian madu rambutan topikal 1 $\mathrm{mL}$ berpengaruh menurunkan kadar MDA pada hari ke-3 (fase inflamasi) dan ke-14 (fase remodeling). Hal ini sesuai dengan penelitian sebelumnya bahwa madu rambutan secara in vitro terbukti menurunkan kadar MDA. ${ }^{20}$ Pengaruh madu rambutan dibandingkan dengan kelompok perlakuan lainnya terlihat. Penelitian pada hewan coba dengan proses selular dan humoral kompleks dapat membantu menjelaskan mekanisme aktivitas antioksidan madu rambutan terlihat dari penurunan kadar radikal bebas dalam tubuh tikus diabetes yang mengalami perlukaan. Kondisi ini menjelaskan bahwa kadar malondialdehid dapat menjadi prognosis suatu kondisi penyakit..$\underline{ }$

Proses perlukaan pada mukosa mulut tikus diabetes melitus melibatkan komponen selular mulai dari proses hemostasis fase inflamasi (ke-3). $\frac{16}{}$ Neutrofil dan sel-sel inflamasi lain saat menelan bakteri mengalami reaksi dalam mitokondria melibatkan NADPH oksidase menyebabkan respiratory burst yang menghasilkan sejumlah besar derivat oksigen radikal bebas misalnya $\mathrm{O}_{2}^{-}, \mathrm{H}_{2} \mathrm{O}_{2}$, $\mathrm{OH}^{*}$. Fase proliferasi dan remodeling (hari ke-7 dan ke-14) melibatkan banyak sel fibroblas yang mengalami reaksi oksidasi biologis penghasil radikal bebas. Radikal bebas akan menginisiasi terjadinya peroksidasi lipid menghasilkan MDA pada jaringan luka termasuk luka di jaringan mulut. $\stackrel{22,23}{ }$ Dengan meningkatnya radikal bebas di fase inflamasi selain dibutuhkan 
untuk proses penyembuhan luka apabila berlebihan akan merusak sel normal sehingga dengan adanya peredaman radikal bebas berlebih oleh madu di fase ini akan membantu proses penyembuhan luka berjalan optimal. $\underline{24}$

Penelitian sebelumnya menjelaskan bahwa kandungan flavonoid dalam madu adalah zat yang berperan sebagai antioksidan dan mampu menangkap radikal bebas serta membantu regenerasi sel pada luka tikus tidak diabetes. Hasil penelitian ini menunjukkan terdapat hasil penurunan kadar radikal bebas jaringan luka pada proses penyembuhan terutama pada fase inflamasi dan remodeling. Flavonoid dalam madu rambutan kemungkinan meredam reaksi peroksidasi lipid penghasil MDA melalui lima mekanisme pembersihan senyawa oksigen reaktif atau penurunan konsentrasinya secara lokal, pembersihan ion logam katalitik, pembersihan radikal bebas yang berfungsi sebagai inisiator, pemutusan rantai dari rangkaian reaksi yang diinisiasi oleh radikal bebas, dan meredam reaksi dan membersihkan singlet oksigen dibantu oleh enzim dalam jaringan, seperti superoksida dismutase (SOD), glutathione peroksidase, dan katalase. Madu rambutan menghambat proses oksidasi dari membran sel dan mencegah kerusakan sel yang berakibat mengganggu penyembuhan luka. $\underline{20}$

Hal ini sangat jelas menunjukkan adanya mekanisme aktivitas antioksidan yang baik dari madu rambutan terhadap peredaman kadar radikal bebas MDA pada penyembuhan luka diabetes sehingga diharapkan apabila bahan alam terstandar ini diaplikasikan akan membantu proses penyembuhan luka diabetes melitus di rongga mulut.

\section{KESIMPULAN}

Madu rambutan dapat mempercepat penyembuhan luka dengan menurunkan kadar radikal bebas MDA luka mukosa mulut tikus diabetes melitus.

\section{DAFTAR PUSTAKA}

1. Mun'im A, Azizahwati, Fimani A. Pengaruh pemberian daun sirih merah (Piper cf.fragile, Benth) secara topikal terhadap penyembuhan luka pada tikus putih diabetes. J Bahan Alam Indonesia. 2011;7:5-12.

2. WHO. Global Report on Diabetes [Internet]. Genewa; 2016. Available from:

https://apps.who.int/iris/bitstream/handl e/10665/204871/9789241565257_eng.p df;jsessionid=BB86110A8C24D660FE CDC9BE59FF40DB? sequence $=1$.

3. Feingold KR, Funk JL. Pathophysiology of disease an introduction to clinical medicine 7th ed. Stamford: Appleton \& Lange. 2014:430-45 p.

4. Kolluru GK, Bir SC, Kevil CG. Endothelial dysfunction and diabetes: effects on angiogenesis, vascular remodeling, and wound healing. IJVM. 2011;2012:1-30.

5. Wientarsih I, Winarsih W, Sutardi LN. Aktivitas penyembuhan luka oleh gel fraksi etil asetat rimpang kunyit pada mencit hiperglikemia. Jurnal Veteriner. 2012;13(2):251-56.

6. Vasudevan DM, Sreekumari S, Vaidyanathan K. Textbook of biochemistry for medical students. 6th ed. New Delhi: Jaypee Bothers Medical Publisher. 2011;236-39 p.

7. Marlina N, Yuslianti ER, Adiantoro S. Pengaruh madu rambutan terhadap penyembuhan luka eksisi mukosa mulut tikus galur wistar dilihat dari luas luka dan vaskularisasi. Bionatura-Jurnal Ilmu-ilmu Hayati dan Fisik. 2014; 16(3):172-75.

8. Yuslianti ER, Boy M.Bactiar, Dewi F. Suniarti, Afifah B.Sutjiatmo. Rambutan honey pharmaceutical standardization for wound healing. Bionatura. 2018; 17(1):1-10. 
9. Yuslianti ER. Rambutan honey induced fibroplasia oral wound healing by TGF$\beta 1$ inhibit MDA-formation. IADR sea division annual scientific meeting: improving quality of life through dental research. Proceeding book. Agustus 2015:246 p.

10. White JW. Composition of honey. in: honey. a comprehensive survey. Crane E, ed. London: Heinemann; 1979.

11. Apriani D, Gusnedi, Darvina Y. Studi tentang nilai viskositas madu hutan dari beberapa daerah di Sumatra Barat untuk mengetahui kualitas madu. Pillar of Physics. 2013;2:91-98.

12. Rosita. Berkat madu, sehat, cantik, dan penuh vitalitas. Bandung Nature Cures; 2007. 33 p.

13. Fakultas Kedokteran Universitas Jenderal Achmad Yani. Buku pedoman praktikum biomedik dasar 1. Cimahi. Fakultas Kedokteran Unjani Press. 2019.

14. Peterson Larry J., Edward lii Ellis., Hupp James R. Contemporary oral and maxillofacial surgery. 6th ed. Missouri: Mosby. 2007:49-62 p.

15. Sjamsuhidajat R, de jong W. Buku ajar ilmu bedah. Edisi 2. Jakarta: EGC;2004:73 p.

16. Bloom L Fawcett DW. Buku ajar histologi 12th ed. Jakarta EGC. 2002:510-12 p.

17. Fanny YR. Aktivitas madu kelengkeng dan madu rambutan terhadap kadar malondialdehid plasma darah dibandingkan dengan vitamin $\mathrm{C}$ (in Vitro). Cimahi: Universitas Jendral Achmad Yani. 2011.

18. Rohmatussolihat. Antioksidan, penyelamat sel-sel tubuh manusia. BioTrends. 2009;4(1):5-9.

19. Sang-Chul Kim, Ok-Su Kim, Ok-Joon Kim, Young-Joon Kim, Hyun-Ju Chung. Antioxidant profile of whole saliva after scaling and root planning in periodontal disease. J Periodontal Implant. 2010;40 (4):164-71.

20. Yuslianti ER, Bachtiar BM, Suniarti DF, Sutjiatmo AB. Antioxidant Activity of Rambutan Honey: The free radical-scavenging activity in vitro and lipid peroxidation inhibition of oral mucosa wound tissue in vivo. RJMP. 2015; 9 (6): 284-92.

21. Arkhaesi N. Kadar malondialdehid (MDA) serum sebagai indikator prognosis keluaran pada sepsis neonatorum [tesis]. Semarang: Program Pascasarjana Magister Ilmu Biomedik Dan Program Pendidikan Dokter Spesialis-I Ilmu Kesehatan Anak Universitas Diponegoro.

22. Yogasedana IMA, Mariati NW, Leman MA. Angka kejadian stomatitis apthosa rekuren (SAR) ditinjau dari faktor etiologi di RSGMP FK Unsrat Tahun 2014. e-Gigi (eG). 2015;3:27884.

23. Avery JK, Chiego DJ. Essential of oral histology and embryology a clinical approach. 5nd ed. Misso: Elsevier; 2018.

24. Murray R.K, Granner D.K, Rodwell V.W. Biokimia Harper. Edisi 27. Alih bahasa Pendit B.U. Jakarta: EGC; 2009:647-52 p. 